\title{
Rola zasobów krajobrazu kulturowego obszarów wiejskich w procesie odnowy wsi i rozwoju lokalnego na przykładzie Długiej Gośliny w województwie wielkopolskim
}

\section{Role of cultural landscape resources of rural areas in the process of rural renewal and local development. Case of Długa Goślina in the Wielkopolskie Province}

\author{
Magdalena SZCZEPAŃSKA ${ }^{1} \bullet$ Agnieszka WILKANIEC ${ }^{2}$ \\ ${ }^{1}$ Uniwersytet im. Adama Mickiewicza w Poznaniu \\ Instytut Geografii Społeczno-Ekonomicznej i Gospodarki Przestrzennej \\ ul. Krygowskiego 10, 61-680 Poznań \\ szmagda@amu.edu.pl \\ ${ }^{2}$ Uniwersytet Przyrodniczy w Poznaniu \\ Wydział Ogrodnictwa i Architektury Krajobrazu \\ ul. Dąbrowskiego 15, 60-594 Poznań \\ ktzagawi@up.poznan.pl
}

Zarys treści: Na obszarach wiejskich występuje bogactwo historycznych zasobów krajobrazu kulturowego, które mogą stanowić o rozwoju społeczno-gospodarczym tych terenów. Ochrona tych zasobów powinna mieć charakter proaktywnych działań wpływających na jakość krajobrazu oraz funkcjonalność tych obszarów. Celem studialnych badań krajobrazowych prowadzonych we wsi Długa Goślina w województwie wielkopolskim było określenie działań w ramach odnowy wsi, w formie potencjalnych wariantów (scenariuszy) rozwoju, możliwych do zaimplementowania również w innych jednostkach osadniczych.

Długa Goślina wykazuje cechy typowe dla wielkopolskiej wsi - ograniczanie funkcji rolniczych na rzecz funkcji mieszkaniowych i usługowych, co powoduje deformację historycznego układu wsi. Wieś ta charakteryzuje się znaczną różnorodnością pod względem zasobów krajobrazu kulturowego, które odpowiednio zinterpretowane i zagospodarowane mogą stanowić istotne podstawy rozwoju lokalnego. W wyniku badań zaproponowano jako możliwy do realizacji scenariusz rozwoju turystyki kulturowej. Wariantem opcjonalnym lub równoległym - z racji funkcjonujących gospodarstw rolnych oraz bliskiego rynku zbytu - byłby rozwój w oparciu o koncepcję rolnictwa ekologicznego.Wydaje się, że zaproponowane warianty-scenariusze mają uniwersalny charakter i przy odpowiedniej ich adaptacji do lokalnych uwarunkowań mogą znaleźć zastosowanie w przedsięwzięciach odnowy wsi na terenie Wielkopolski.

Słowa kluczowe: zasoby i zagrożenia krajobrazu kulturowego, wyróżniki krajobrazu, odnowa wsi, rozwój wielofunkcyjny wsi, rozwój lokalny, tematyzacja wsi. 


\section{Wprowadzenie}

Kształtowanie i ochrona krajobrazu jest od wielu lat przedmiotem badań naukowców z różnych dziedzin. Istotny wkład w rozwój tego interdyscyplinarnego zagadnienia mają również geografowie i urbaniści. Kompleksową i do dziś stosowaną w geografii regionalizację fizycznogeograficzną Polski opracował i doskonalił J. Kondracki (1976). Szeroko rozumianą ekologią krajobrazu zajmują się współcześnie jego następcy A. Richling i J. Solon (1994). Wśród najnowszych opracowań należy wymienić typologię krajobrazu (Chmielewski i in. 2015), opracowania dotyczące metod identyfikacji i oceny (Solon i in. 2015) oraz oceny wartości i zagrożeń krajobrazów (Myga-Piątek 2014). Zmiany zakresu znaczeniowego pojęcia krajobrazu kulturowego i jego niejednoznaczności opisuje F. Plit (2016). Aktualnym w kontekście klasyfikacji i kształtowania krajobrazów wiejskich wydaje się opracowanie R. Cymermana i in. (1992). Natomiast J. Bogdanowski (1976), autorytet w zakresie architektury krajobrazu, zdefiniował krajobraz kulturowy jako przestrzeń ukształtowaną w wyniku działalności dawniej i obecnie żyjących społeczności, zawierającą wytwory cywilizacji i elementy przyrodnicze. Zależność cech środowiska i możliwości wytwórczych społeczeństwa najpełniej uwidacznia się w architekturze, strukturze użytkowania ziemi, zróżnicowaniu upraw i jest szczególnie czytelna w skali regionu, świadcząc o jego materialnym i niematerialnym dziedzictwie. Współczesny krajobraz kulturowy posiada zwykle bardzo złożoną strukturę, która powstała w wyniku nawarstwienia wielowiekowych przemian.

Walory przyrodnicze, jak i zasoby kulturowe krajobrazu, są szczególnym czynnikiem wielofunkcyjnego rozwoju obszarów wiejskich (Kostrowicki 1976; Kłodziński 1996; Heffner 2001; Bański i Stola 2002). Pełne i harmonijne wykorzystanie zasobów kulturowych danego obszaru stanowi podstawową przesłankę rozwoju lokalnego opartego na czynnikach endogenicznych (Parysek 2001; Murzyn-Kupisz 2012). Obiekty dziedzictwa podnoszą przede wszystkim atrakcyjność turystyczną regionu i zwiększają jego konkurencyjność, dlatego najbardziej popularnym narzędziem stymulującym rozwój lokalny, wykorzystującym jednocześnie dziedzictwo, jest turystyka (Hełpa-Liszkowska 2013). Warto również zwrócić uwagę, że oczekiwania turystów związane są nierzadko z doświadczaniem tradycyjnego i regionalnego charakteru przestrzeni, stąd lokalne społeczności oraz władze samorządowe coraz częściej dostrzegają potrzebę zachowania odrębności miejscowo występujących wzorców przestrzennych, a nawet ich odnowy (Wilczyński 2000). Zatem jednym z najważniejszych problemów kształtowania krajobrazu obszarów wiejskich jest zachowanie tożsamości kulturowej. Rozwiązanie tego problemu nie może sprowadzać się wyłącznie do ochrony zewnętrznego wizerunku wsi i jej walorów widokowych czy powierzchownych zabiegów estetyzacji. Podstawą dobrych rozwiązań projektowych jest zrozumienie szczególnych związków osób z zamieszkiwaną przez nich przestrzenią (Raszeja 2013). Ważne jest określenie elementów wyróżniających wieś, które pomogą nie tylko w identyfikacji danej przestrzeni, ale również w przyszłych działaniach i inwestycjach podporządkowanych całościowej wizji rozwoju uwzględniającej specyficzny charakter obszaru. Elementy charakterystyczne mają zatem być inspiracją do tworzenia obiektów nowych, uwzględniających współczesne standardy, jednak spójnych z tym, co zostało już wcześniej stworzone (Niedźwiecka-Filipiak 2009).

Studialne badania krajobrazowe prowadzono na terenie wsi Długa Goślina w województwie wielkopolskim. Celem badań było sformułowanie uniwersalnych działań w ramach odnowy wsi, w formie potencjalnych wariantów (scenariuszy) rozwoju, możliwych do zaimplementowania również w innych jednostkach osadniczych. 


\section{Krajobraz kulturowy obszarów wiejskich a odnowa i rozwój wsi}

O krajobrazie kulturowym obszarów wiejskich stanowi przede wszystkim charakter jego kompozycji i układy przestrzenne. Ważna jest geometria przestrzeni, sposób jej zagospodarowania w trzecim wymiarze, proporcje obszarów zabudowanych do niezabudowanych, oddziaływanie między elementami pochodzenia naturalnego i kulturowego. Dziedzictwo materialne wsi to jej układ pól uprawnych i siedliska oraz rozplanowanie zagród, forma, materiał i konstrukcja zabudowy mieszkaniowej i gospodarczej, a także detal architektoniczny. Szczególne znaczenie w kontekście rozplanowania przestrzennego wsi ma umiejscowienie takich obiektów jak: plac, kościół, cmentarz, kapliczka, dwór, park lub folwark. W przypadku zasobów krajobrazowych wsi niezmiernie istotnym walorem jest ekspozycja krajobrazowa zabudowy, rozłogu pól i poszczególnych obiektów w otaczającej przestrzeni (Bogdanowski 1996). O specyfice krajobrazu kulturowego wsi stanowi również skład gatunkowy zieleni przydomowej, alejowej czy zadrzewień śródpolnych, a także zasoby niematerialne, tj. lokalne tradycje kulinarne, obyczaje, zawody i umiejętności czy gwara (Konopka 2001; Duriasz-Bułhak i in. 2011).

Współczesne procesy społeczne i gospodarcze oraz towarzyszące im zjawiska przestrzenne na obszarach wiejskich należy rozpatrywać w kontekście ogólnych tendencji rozwojowych, ukierunkowanych przez różne siły ekonomiczne, społeczne i polityczne (Parysek 2008). Aktualnie tereny wiejskie, zwłaszcza te położone w strefie podmiejskiej dużego miasta, podlegają silnej presji urbanizacyjnej - urban sprawl, co prowadzi do zachwiania ich stabilności ekologicznej, deformacji struktury funkcjonalno-przestrzennej i degradacji krajobrazu (Raszeja i in. 2010; Wójcik 2013). Zjawiska te dotyczą również terenów wiejskich zlokalizowanych wzdłuż głównych tras komunikacyjnych oraz terenów cennych przyrodniczo i krajobrazowo (Głębocki 2008). Dodatkowym zagrożeniem prowadzącym do utraty cennych zasobów krajobrazu kulturowego wsi jest problem ze zdefiniowaniem pojęcia wieś, typologią i delimitacją obszarów wiejskich (Bański 2008, 2014). Ponadto szczególnie niepokojący wydaje się brak skutecznych narzędzi ochrony, ograniczenia finansowe oraz często niska świadomość krajobrazowa zarówno społeczności lokalnej, jak i władz samorządowych (Szczepańska 2014). Wśród współczesnych zagrożeń walorów krajobrazu i dziedzictwa i kulturowego wsi należy wymienić m.in.: rozpraszanie zabudowy, przenoszenie miejskich wzorców architektonicznych, obecność wielkokubaturowej i wysokościowej zabudowy, brak ochrony cennych widoków i stref ekspozycji panoram, zanik tradycyjnych elementów krajobrazu rolniczego, a także deformację i zanik tradycyjnych ogrodów przydomowych (Raszeja i in. 2010).

Podejmowane dotąd działania zaradcze wobec wielowymiarowego kryzysu obszarów wiejskich prowadziły do „umiastowienia” wsi i uprzemysłowienia rolnictwa, czego skutkiem jest zanik indywidualności oraz tożsamości, a tym samym degradacja wiejskiego krajobrazu kulturowego. Odpowiedzią na przemiany cywilizacyjne stała się idea odnowy, polegająca na poszukiwaniu koncepcji rozwojowych zgodnych ze specyfiką przyrodniczą, społeczną, gospodarczą i kulturową obszarów wiejskich, opartych na lokalnych zasobach i przy udziale lokalnych społeczności (Wilczyński 2003). Za priorytetowy cel odnowy wsi należy uznać poszukiwanie jej odrębności i niepowtarzalności architektoniczno-przestrzennej. Zdaniem I. Niedźwieckiej-Filipiak (2015) badania powinny koncentrować się na identyfikacji specyficznych cech i form krajobrazu, jako podstawy budowania projektu. Każda miejscowość może mieć wiele identyfikatorów - wyróżników, lecz jeden z nich powinien 
mieć rangę wiodącą, a pozostałe wspomagającą i uzupełniającą. Zasadniczo wyróżniki możemy podzielić na przyrodnicze i antropogeniczne, w tym niematerialne i materialne. W definiowaniu wyróżników istotne jest także miejsce ich występowania w krajobrazie: wewnętrzne - rozumiane jako struktura wsi w granicach terenów zabudowanych miejscowości oraz zewnętrze jako jej otoczenie (rozłóg pól).

Według I. Niedźwieckiej-Filipiak (2007) przedsięwzięcia podejmowane w ramach odnowy wsi można podzielić na: proste (charakterystyczne dla fazy inicjalnej) oraz kompleksowe - istotne z punktu widzenia rozwoju regionu (realizowane w fazie zaawansowanej). Wśród prostych projektów należy wymienić: próby zagospodarowania przestrzeni wspólnych, porządkowanie i urządzanie otoczenia obiektów użyteczności publicznej, adaptacji obiektów lub pomieszczeń na nowe funkcje. Podejście kompleksowe oznacza realizację projektów uwzględniających całościowe, strategiczne wizje rozwoju zgodne z dziedzictwem kulturowym i historycznym krajobrazem wsi lub ukierunkowanie ich rozwoju w stronę nowych, wiodących typów działalności - specjalizacji, czego wyrazem może być zaistnienie wsi tematycznej.

Wydaje się, że w ostatnich latach turystyka kulturowa, związana z rozwojem lokalnym, cieszy się dużą popularnością. Planując jej rozwój, należy jednak pamiętać o pewnych niebezpieczeństwach związanych przede wszystkim z tym, że dziedzictwo kulturowe, zwłaszcza w swoich niematerialnych przejawach, jest bardzo wrażliwe. Tworzenie produktu turystyki kulturowej musi być poprzedzone dokładnym rozpoznaniem lokalnych zasobów i potrzeb rynku. Często z bogactwa dziedzictwa nie zdają sobie sprawy sami jego spadkobiercy, dlatego warto, aby promocja takiego produktu skierowana była zarówno do turystów, jak i do lokalnej społeczności (Małek 2003). Największy atut produktów regionalnych to oryginalny sposób wytwarzania przekazywany z pokolenia na pokolenie oraz jakość przewyższająca wyraźnie jakość towarów produkowanych masowo (Hełpa-Liszkowska 2013; Kruczek i Walas 2009). Przykładem łączącym turystykę kulturową z produktami tradycyjnymi są wioski tematyczne, których rozwój jest podporządkowany konkretnej idei, tematowi, np. Wioska Garncarska, Górnicza, Kwiatowa. Wieś koncentrująca się na określonym kierunku, temacie rozwoju, w porównaniu z innymi wsiami o podobnym stanie wyjściowym rozwija się lepiej pod względem gospodarczym i społecznym (Idziak 2008). Proces tworzenia wioski tematycznej jest w dużej mierze partycypacyjny, a w jego trakcie następuje aktywizacja i wzmacnianie kapitału społecznego (Czapiewska 2012). Natomiast rozkład przestrzenny wiosek tematycznych wskazuje, że łatwiej jest utworzyć taką na terenach o mniejszych szansach rozwojowych (Kłoczko-Gajewska 2014). Istotne jest, aby w procesie poszukiwania tematu wsi czerpać z lokalnych zasobów krajobrazu kulturowego. Przykładem tematyzacji w większej skali obszaru, z wykorzystaniem budowlanych tradycji regionalnych, mogą być „Kraina w kratę” lub „Kraina otwartych okiennic”. Szczególną szansą na ożywienie wsi i stworzenie produktu turystycznego w skali kraju wydaje się być koncepcja „Sieci najciekawszych wsi”. Jest to propozycja wykorzystania walorów kulturowych, przyrodniczych, krajobrazowych oraz ładu przestrzennego na rzecz rozwoju turystyki wiejskiej w Polsce, zaadresowana do grupy wsi, które nadal dysponują takimi walorami oraz miejscowości, gdzie walory te można przywrócić (Wilczyński 2012). 


\section{Historia i uwarunkowania rozwoju obszaru badań}

Wieś sołecka Długa Goślina położona jest w województwie wielkopolskim, w powiecie poznańskim, w gminie miejsko-wiejskiej Murowana Goślina, około 30 km od Poznania (ryc. 1).

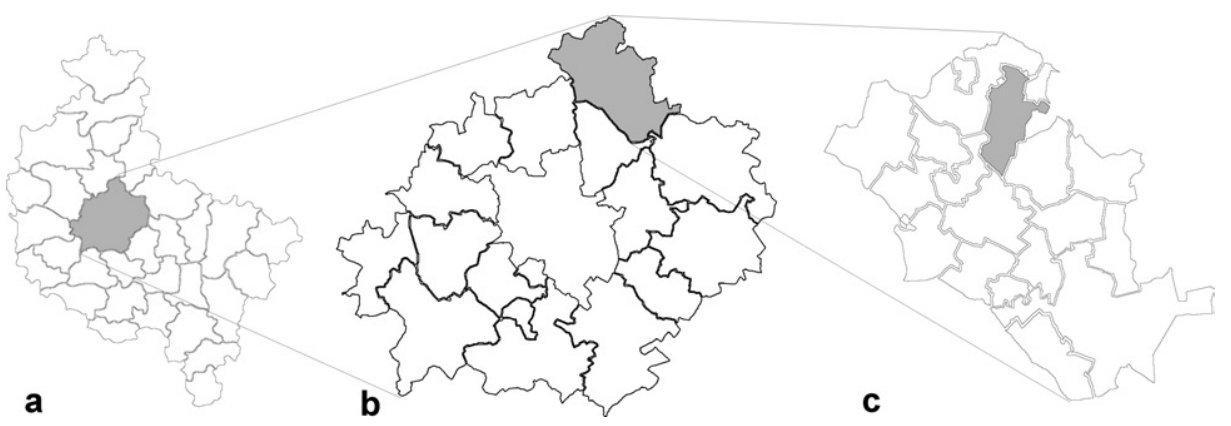

Ryc. 1. Obszar badań: a - województwo wielkopolskie, b - powiat poznański, c - gmina Murowana Goślina Źródło: opracowanie własne.

Area under study: $a$ - Wielkopolskie Province, $b$ - Poznań County, c-Murowana Goślina commune Source: own elaboration.

W 1932 r. odkopano tu osadę wczesnośredniowieczną, stanowiącą rycerską własność ziemską, w której odnaleziono srebrny skarb, ceramikę i kości zwierząt domowych, a także złote monety zwane staterami (Szafrański 1975). Początkowo najprawdopodobniej cały obszar nosił jedną wspólną nazwę „Gostlin”, a następnie "Goślina” od imienia Gościsława lub Gościmira. W wyniku zróżnicowania własnościowego na początku XIII w. wsie otrzymały odrębne określenia, które miały podkreślać ich specyfikę. Pierwszy człon nazwy analizowanej wsi wskazuje na zasięg zabudowy wiejskiej, która rozciąga się wzdłuż jednej drogi, po obu jej stronach (Brust 2004). Następnie Długa Goślina (z niem. Langgoslin) podlegała kolonizacji na prawie niemieckim, natomiast sąsiadujące ze wsią tereny i miejscowości posiadają ślady osadnictwa olenderskiego. W Długiej Goślinie od XVII w. funkcjonowała karczma oraz młyn wodny, który uległ spaleniu. W 1620 r. wieś przejęły siostry Benedyktynki, fundatorki drewnianego kościoła, obecnie uznanego za zabytek (Kulse i Wojczak 2004). Na początku XIX w. Długą Goślinę zamieszkiwało 198 osób, w tym 134 katolików i 64 ewangelików. Znajdował się tu folwark i 12 domów oraz poczta (Sulimierski 1880). Poza zabudową zagrodową w pierwszej połowie XIX w. na terenie wsi powstał dwór w stylu późnoklasycystycznym. Z obiektem tym związane było założenie parkowe, niestety nie zachowało się ono do dziś. Obiekt dworski natomiast uległ znacznym przekształceniom. W połowie XIX w. dobudowano neogotyckie skrzydło. W 1817 r. wieś została przejęta na rzecz skarbu państwa pruskiego (Kulse i Wojczak 2004). W 1912 r. wybudowano szkołę, która funkcjonuje do dziś. Wieś Długa Goślina stanowi obecnie jedno z 18 sołectw gminy Murowana Goślina. Znajdują się tu 2 sklepy oraz kilka zakładów usługowych, w tym gospodarstwo agroturystyczne, działa ośrodek pomocy społecznej oraz ochotnicza straż pożarna. Wieś posiada wodociąg i kanalizację i jest obsługiwana przez PKS. Charakteryzuje ją zróżnicowany krajobraz osadniczo-rolniczy (28 gospodarstw rolnych), który jednak jest degradowany na skutek rozwoju funkcji mieszkaniowej i usługowej. W 2011 r. liczba mieszkańców wsi wynosiła 353. W latach 1998-2015 wskaźnik dynamiki wzrostu 
ludności w gminie wyniósł 141 (GUS 2016), co przekłada się na dość intensywny rozwój budownictwa mieszkaniowego. Najważniejszym zasobem przyrodniczym gminy jest Park Krajobrazowy Puszcza Zielonka, natomiast wśród walorów kulturowych należy wymienić „Wielkopolską Drogę Świętego Jakuba” oraz „Cysterski Szlak Rowerowy”, a także "Szlak drewnianych kościołów wokół Puszczy Zielonki” (Kaleniewicz 2008). Ponadto miasto Murowana Goślina, jako jedyne w województwie wielkopolskim, należy do Cittaslow - Międzynarodowej Sieci Miast Dobrego Życia.

\section{Procedura badawcza i wyniki badań}

Po rozpoznaniu historycznych i współczesnych uwarunkowań rozwoju lokalnego analizowanej wsi, w celu ustalenia wariantów (scenariuszy) jej odnowy, zastosowano następującą procedurę badawczą:

- Na podstawie analizy porównawczej archiwalnych map stolikowych (Messtischblatt 1940), współczesnych map topograficznych i ortofotomap zweryfikowanych badaniami terenowymi dokonano oceny stopnia zachowania historycznych układów przestrzennych, stosując metodę bonitacyjną (Szczepańska i Wilkaniec 2014).

- Przeprowadzono badania krajobrazowe w zakresie analizy ekspozycji panoramy wsi w krajobrazie oraz zasięgu widoków i przedpola widokowego.

- Wyróżniono jednostki architektoniczno-krajobrazowe - JARK (Bogdanowski 1994).

- Zidentyfikowano wyróżniki krajobrazu (Filipiak-Niedźwiecka 2009).

- Przeanalizowano dokumenty planistyczne dla badanej jednostki (tj. studium uwarunkowań i kierunków zagospodarowania przestrzennego gminy, miejscowe plany, strategię rozwoju, plan odnowy wsi).

- Na poziomie gminy określono powiązania funkcjonalno-przestrzenne, komunikacyjne, infrastrukturalne i przyrodniczo-kulturowe; na poziomie wsi - stan rolniczej przestrzeni produkcyjnej, środowiska przyrodniczego i kulturowego.

- Zebrane informacje poddano analizie SWOT (analiza silnych i słabych stron oraz szans i zagrożeń) wobec rozwoju lokalnego.

Z przeprowadzonej oceny stopnia zachowania historycznych układów przestrzennych, metodą bonitacji punkowej ${ }^{1}$ (Szczepańska i Wilkaniec 2014), wynika że do obecnych czasów największą trwałość wykazał układ komunikacyjny (5) oraz aleje (5), w znacznym stopniu zachował się także historyczny układ przestrzenny jednostki osadniczej (4), układ gruntów i rodzaj ich użytkowania, rozplanowanie zagród oraz pokrycie terenu (4), ze szczególnym uwzględnieniem sadów i zadrzewień śródpolnych. Najmniej trwałą strukturą okazało się założenie folwarczne (2) - do obecnych czasów przetrwała jedynie gorzelnia, przy czym jej stan jest niezadowalający. Podobną trwałość wykazało założenie rezydencjonalno-parkowe (2), sam dwór został przekształcony, natomiast park nie zachował się (ryc. 2). Wskaźnik trwałości historycznych układów przestrzennych wsi wynosi 57\%, zatem Długa Goślina jako wieś o przeciętnej wartości wskaźnika może stanowić przykład typowych przekształceń krajobrazu wielkopolskich wsi.

1 Skala: „5" - stan dobry, "4" - stan dobry przekształcony, „3” - stan przekształcony zaniedbany, "2" - stan przekształcony zdegradowany, "1" - stan zachowany śladowo, „0" - nie dotyczy, „-1" - nie zachowany. 

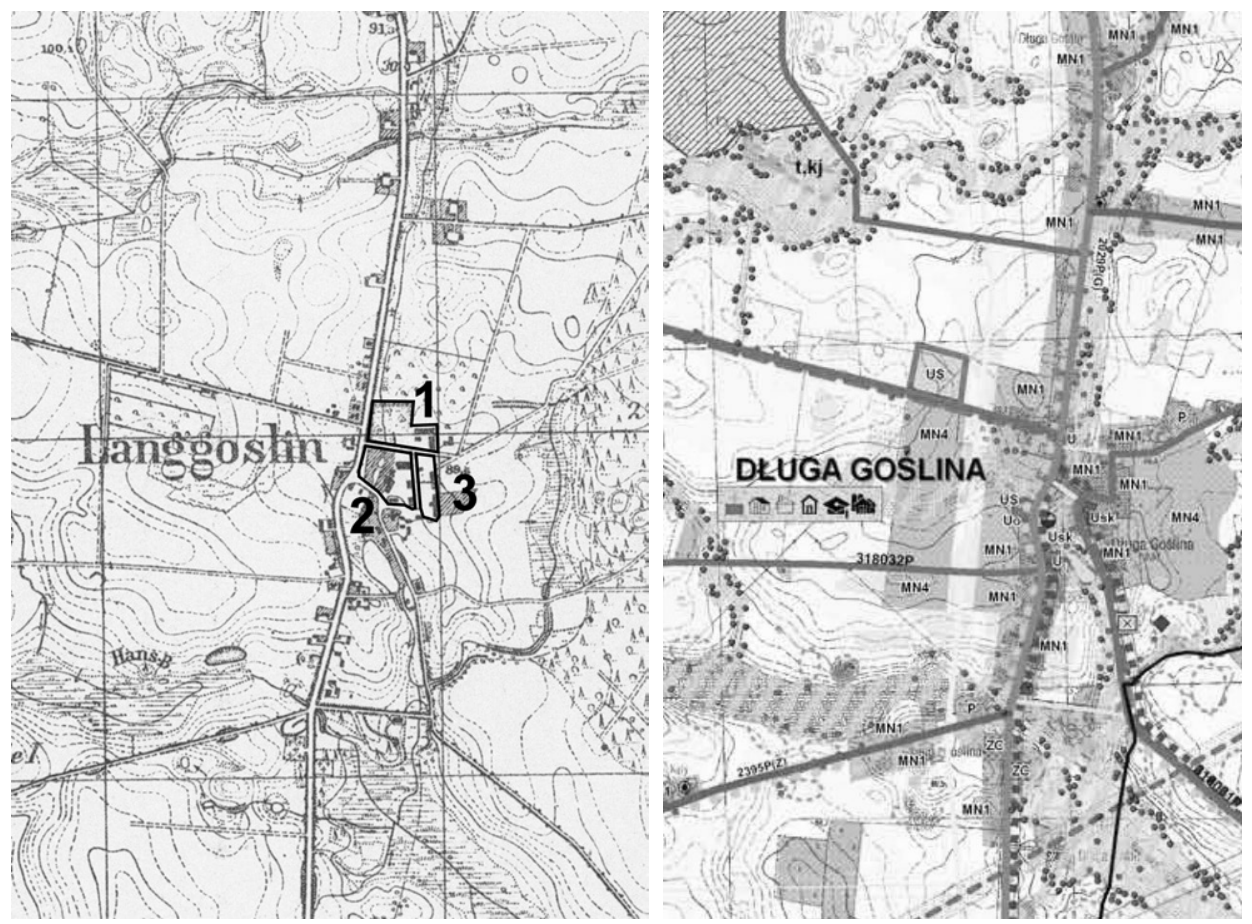

Ryc. 2. Historyczna i projektowana struktura przestrzenna wsi Długa Goślina 1 - park, 2 -dwór, 3 - folwark.

Źródło: Messtischblatt 1940 (http://mapy.amzp.pl); Kierunki zagospodarowania przestrzennego wsi Długa Goślina (Studium... 2009).

Historical and projected spatial structure of Długa Goślina village

1 - park, 2 - court, 3 -grange.

Source: Messtischblatt 1940 (http://mapy.amzp.pl); The directions of spatial development of Długa Goślina village (Studium... 2009).

Metodą JARK (Bogdanowski 1994) wyodrębniono 14 jednostek architektoniczno-krajobrazowych, analiza wskazała na przewagę harmonijnego krajobrazu rolniczego (ryc. 3).

Natomiast analiza zasięgów widoków wykazała dobrą ekspozycję widokową wsi. Niestety obserwuje się postępujący zanik dotychczasowej, lokalnej tradycji budowlanej. Tendencje współczesnego budownictwa, przejawiające się w rodzaju stosowanych materiałów oraz specyficznych formach i kubaturach wznoszonych budynków, przyczyniają się do degradacji historycznego krajobrazu wsi. Jest to szczególnie widoczne na przykładzie zakłóceń powstałych w przedpolu widokowym zabytkowego, drewnianego kościoła i dworu (ryc. 4).

Dla badanej wsi ustalono następujące wyróżniki krajobrazu: formy zieleni, obiekty użyteczności publicznej, zabudowę zagrodową oraz detal architektoniczny (ryc. 5). We wsi znajdują się cenne zasoby krajobrazu kulturowego: drewniany kościół jako dominanta, dwór, gorzelnia, jako pozostałość dawnego folwarku, zabudowa zagrodowa oraz zespoły zieleni komponowanej - wysokiej: aleje, sady, zadrzewienia przyzagrodowe i śródpolne.

Znaczącą rolę w procesie przekształcania krajobrazu wsi odgrywają zmiany charakteru i przeznaczenia ogrodów przydomowych. Dotychczasowe przedogródki kwiatowo-zielne coraz częściej są przekształcane w typowo ozdobne, wykorzystujące w większości nowe 


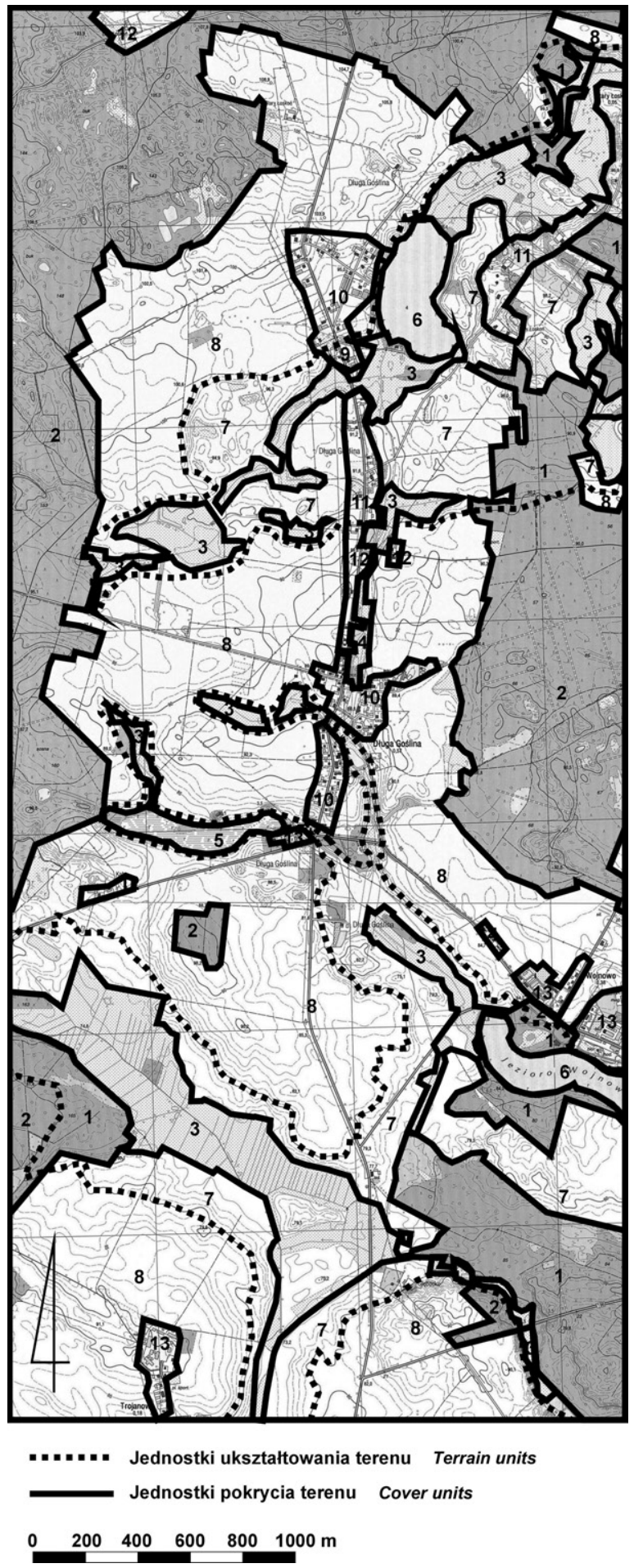

Ryc. 3. Jednostki architektoniczno-krajobrazowe wsi Długa Goślina 1 - las w dolinach cieków wodnych; 2- las w terenie pofalowanym; 3 - szuwary w dolinach cieków wodnych; 4 - szuwary w terenie pofalowanym; 5 - teren podmokły $w$ dolinie cieku wodnego; 6 - jeziora w dolinie cieków wodnych; 7 - pola uprawne z zadrzewieniami w dolinach cieków wodnych; 8 - pola uprawne z zadrzewieniami w terenie pofalowanym; 9 - zabudowa zagrodowa zwarta w dolinach cieków wodnych; 10 - zabudowa zagrodowa zwarta w terenie pofalowanym; 11 - zabudowa zagrodowa rozproszona w dolinach cieków wodnych; 12 - zabudowa zagrodowa rozproszona w terenie pofalowanym; 13 -zabudowa gospodarcza w terenie pofalowanym; 14 - zabudowa mieszkaniowa $w$ terenie pofalowanym. Źródło: opracowanie własne. Architectural and landscape units of Długa Goślina village

1 -forest in valleys of watercourses; 2 -forest in undulating area; 3 -rushes in valleys of watercourses; 4 - rushes in undulating area; 5 - wetland in valley of the watercourse; 6 -lakes in valley of watercourses; 7 -cultivated fields with shelterbelts in valleys of watercourses; 8 -cultivated fields with shelterbelts undulating area; 9 -compact farmstead buildings in valleys of watercourses; 10 - compact farmstead buildings in the undulating area; 11 - scattered farmstead buildings in valleys watercourses; 12 -scattered farmstead buildings in the undulating area; 13 - outbuildings in the undulating area; 14 - residential buildings in the undulating area.

Source: own elaboration. 

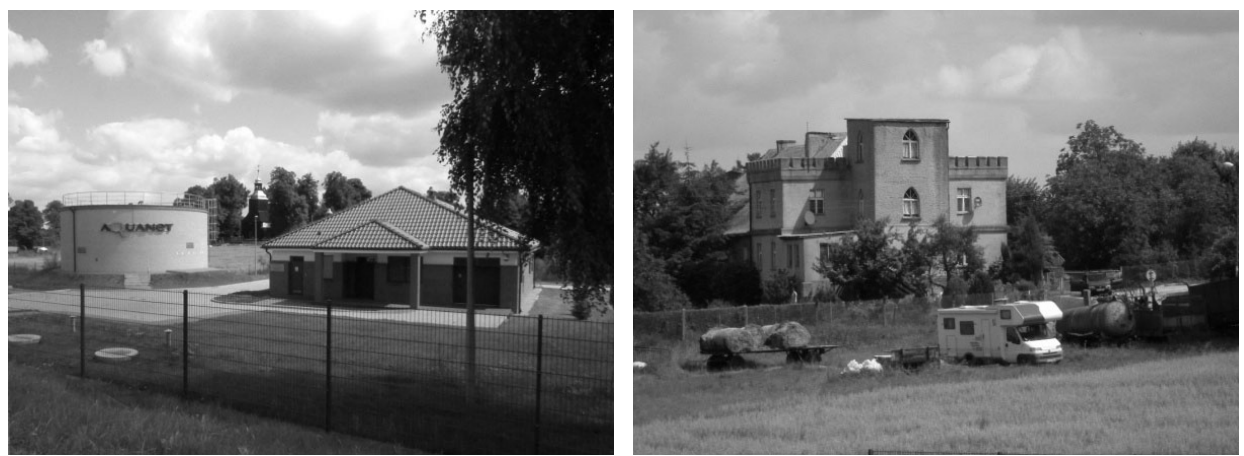

Ryc. 4. Degradacja przedpola ekspozycji kościoła i dworu (fot. M. Szczepańska 2015) Degradation foreground exposure of church and mansion (photo by M. Szczepańska 2015)
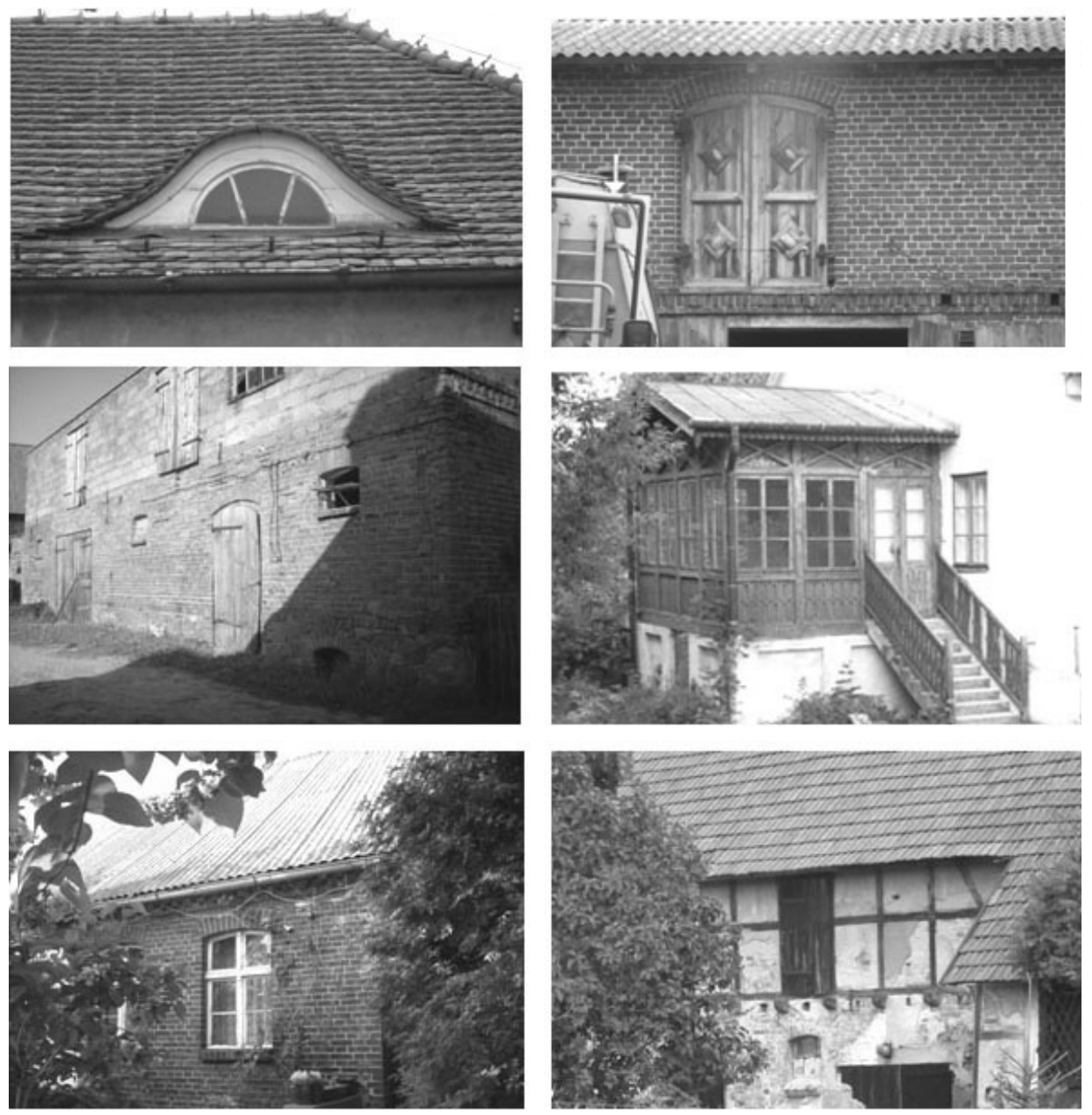

Ryc. 5. Detal architektoniczny jako wyróżnik krajobrazu wsi (fot. M. Szczepańska 2016)

Architectural detail as a distinctive feature of rural landscape (photo by M. Szczepańska 2015) 
odmiany i gatunki roślin, drzew i krzewów, najczęściej obcego pochodzenia, nieznane dotychczas w tradycyjnym krajobrazie polskiej wsi.

W kontekście zasobów krajobrazu kulturowego wsi - dobrze zachowanych historycznych układów przestrzennych wsi oraz wartości krajobrazu rolniczego niepokojące są kierunki zmian wynikające z zapisów Studium uwarunkowań i kierunków zagospodarowania przestrzennego (2009). Wyznaczenie terenu zabudowy mieszkaniowej MN4 w przedpolu widokowym siedliska wsi zaburzy ekspozycję jej czytelnej sylwety w krajobrazie, a MN1 w bezpośrednim sąsiedztwie alei (kierunek Skoki), może w przyszłości negatywnie wpłynąć na zdrowotność i liczebność tworzących ją drzew (ryc. 2). W zapisach Planu Odnowy Sołectwa (2010) określono szereg istotnych zadań inwestycyjnych i modernizacyjnych: budowę kanalizacji sanitarnej, gazyfikację, budowę i modernizację dróg wraz z chodnikami, oświetleniem i ścieżką rowerową, rozbudowę kompleksu sportowego, modernizację sali wielofunkcyjnej i salki strażackiej, budowę sieci internetu szerokopasmowego. Niepokojący jest brak wskazania działań na rzecz odnowy wsi w kontekście jej zasobów krajobrazu i dziedzictwa kulturowego. Zdaniem R. Wilczyńskiego (2007) obecne myślenie o odnowie wsi w Polsce jest zdominowane przez możliwości uzyskania unijnej pomocy. Szansa ta jest jednocześnie największym zagrożeniem dla tej idei rozumianej jako proces przekształcający obszary wiejskie dzięki oddolnemu zaangażowaniu samych mieszkańców. Unijne wsparcie ma przedmiotowy i sektorowy charakter odgórnej punktowo realizowanej interwencji.

Zebrane informacje poddano analizie SWOT, która wykazała przewagę słabych stron oraz znaczącą obecność szans w zakresie rozwoju wsi (tab. 1).

\section{Proponowane warianty rozwoju wsi w ramach jej odnowy}

W świetle studialnych badań krajobrazowych konieczne wydaje się podjęcie wstępnych działań zachowawczych mających na celu utrzymanie dotychczasowego stanu wsi, przy jednoczesnym ograniczeniu dalszych niekorzystnych zmian w krajobrazie. Taki kierunek działań, niedający wymiernego zysku ekonomicznego, może być rozumiany jako przeciwieństwo kierunku inwestycyjnego, warto jednak podkreślić, że nie wymaga on dużych nakładów finansowych. Ten etap powinien mieć charakter przejściowo-wyjściowy, pozwalający zgromadzić fundusze, znaleźć inwestorów, wykonać szczegółowe analizy krajobrazu, opracować kierunki dalszego rozwoju oraz wytyczne projektowe. Byłby to także czas niezbędny na uświadamianie i promowanie wartości kulturowych wśród społeczności lokalnej, a także zawiązanie więzi społecznych, wyłonienie lokalnych liderów i autorytetów. Do działań strategicznych, które mogą ułatwić wykorzystanie i promowanie dziedzictwa kulturowego, należy (Duriasz-Bułhak i in. 2011):

- przygotowanie informacji o świadectwach kultury lokalnej i o żyjących na danym terenie mniejszościach narodowych,

- przygotowanie programu edukacyjnego związanego z poszukiwaniem elementów dziedzictwa niematerialnego,

- umieszczenie informacji o zabytkach dziedzictwa niematerialnego w gminnym programie rewitalizacji, strategii rozwoju gminy, strategii turystycznej gminy, planie ochrony parku narodowego, parku krajobrazowego itp. 
Tabela 1. Mocne i słabe strony, szanse i zagrożenia rozwoju wsi Długa Goślina

\begin{tabular}{|c|c|}
\hline Mocne strony & Słabe strony \\
\hline $\begin{array}{l}\text { - Zachowanie historycznego układu przestrzennego } \\
\text { wsi, podziału i funkcji użytkowania terenu } \\
\text { - Cenne zasoby krajobrazu kulturowego } \\
\text { - Wartościowy kontekst przyrodniczy i sąsiedztwo } \\
\text { obszarów objętych ochroną } \\
\text { - Szczególne walory widokowe i otwarta przestrzeń } \\
\text { wolna od zabudowy } \\
\text { - Atrakcyjny system szlaków turystycznych: pieszych, } \\
\text { rowerowych i konnych } \\
\text { - Aktywny udział wsi w różnorodnych projektach } \\
\text { międzygminnych }\end{array}$ & $\begin{array}{l}\text { - Silne przekształcenia w otoczeniu historycznych } \\
\text { obiektów } \\
\text { - Utrata zespołu folwarcznego oraz } \\
\text { dworsko-parkowego } \\
\text { - Powolny zanik lokalnej tradycji budowlanej } \\
\text { - Niedostateczna promocja wsi i niewystarczające } \\
\text { wykorzystanie istniejącego potencjału kulturowego } \\
\text { - Braki w edukacji i informacji w zakresie dziedzictwa } \\
\text { przyrodniczego i kulturowego } \\
\text { - Braki w zapisach prawnych chroniących krajobraz } \\
\text { kulturowy i realnej kontroli jego ochrony } \\
\text { - Brak fachowego doradztwa oraz realnych zachęt } \\
\text { i propozycji adaptacji obiektów i zespołów cennych } \\
\text { kulturowo } \\
\text { - Monokultura rolnicza }\end{array}$ \\
\hline Szanse & Zagrożenia \\
\hline $\begin{array}{l}\text { - Uporządkowanie przestrzeni publicznej wsi } \\
\text { - Objęcie ochroną obiektów cennych kulturowo i ich } \\
\text { przedpola widokowego } \\
\text { - Ochrona i odtwarzanie zadrzewień śródpolnych, } \\
\text { alei, sadów i tradycyjnych ogrodów przydomowych } \\
\text { - Opracowanie wzornika tradycyjnych form archi- } \\
\text { tektonicznych i wytycznych dla nowej zabudowy } \\
\text { mieszkaniowej } \\
\text { - Wytyczenie ochronnych stref widokowych oraz } \\
\text { wyłączenie spod zabudowy obszarów cennych } \\
\text { krajobrazowo } \\
\text { - Wzmacnianie społecznej świadomości w zakresie } \\
\text { wartości krajobrazu i dziedzictwa kulturowego } \\
\text { - Wzmocnienie promocji i ukierunkowanie rozwoju } \\
\text { wsi } \\
\text { - Rozwój turystyki kulturowej i usprawnienie infra- } \\
\text { struktury turystycznej } \\
\text { - Rozwój rolnictwa ekologicznego ze szczególnym } \\
\text { uwzględnieniem tradycyjnych gatunków i technik } \\
\text { gospodarowania oraz funkcji edukacyjnych } \\
\text { Partycypacja społeczności lokalnej w działaniach } \\
\text { podejmowanych na rzecz wsi } \\
\text { Wsparcie finansowe dla poszczególnych podmio- } \\
\text { tów gospodarczych oraz właścicieli zagrożonych } \\
\text { obiektów }\end{array}$ & $\begin{array}{l}\text { - Rozwój zabudowy o podmiejskim charakterze } \\
\text { w oderwaniu od lokalnej tradycji } \\
\text { - Utrata cennych zasobów architektonicznych } \\
\text { w wyniku niekontrolowanej rozbudowy i prac } \\
\text { modernizacyjnych } \\
\text { - Przenoszenie miejskich wzorców w kształtowaniu } \\
\text { ogrodów przydomowych i doborze roślinności } \\
\text { - Podziały własnościowe gruntów rolnych } \\
\text { - Brak ochronnych stref widokowych }\end{array}$ \\
\hline
\end{tabular}

Źródło: opracowanie własne.

Ponadto do przedsięwzięć niezbędnych na tym etapie odnowy wsi należy wyznaczenie stref szczególnej ochrony krajobrazowej, polegającej na zakazie zmiany dotychczasowego sposobu użytkowania, zakazie wprowadzania nowych elementów zainwestowania (m.in. obiektów wysokościowych, kubaturowych, terenochłonnych), ochronie przedpola ekspozycji widokowej wsi poprzez wprowadzenie stref wolnych od zabudowy jednorodzinnej. W przypadku wsi Długa Goślina będą to działania polegające na:

- wyznaczeniu stref wolnych od zabudowy w celu zachowania ekspozycji widokowej na obiekty związane z dawnym folwarkiem oraz kościołem, co może wiązać się z wykupem przyległego terenu,

- uporządkowaniu przestrzeni wjazdu - wizytówki wsi od strony Murowanej Gośliny oraz sąsiedztwa najcenniejszych obiektów - zabytkowego kościoła i dworu, 
- zminimalizowaniu negatywnych dla krajobrazu skutków decyzji o budowie stacji uzdatniania wody, poprzez zastosowanie niekolidującej z tradycyjnym charakterem wsi zieleni maskującej w postaci pnączy i krzewów, docelowo zieleni wysokiej z zastosowaniem rodzimych gatunków liściastych oraz iglastych,

- zmianie kolorystyki elewacji i formy architektonicznej obiektów użyteczności publicznej, zwłaszcza sklepów oraz uporządkowanie ich otoczenia,

- sformułowaniu spójnej krajobrazowo polityki reklamowej,

- wprowadzaniu zieleni wysokiej towarzyszącej obiektom współczesnej architektury niedopasowanym do kontekstu kulturowego (maskująca funkcja zieleni),

- odtwarzaniu alej i zadrzewień śródpolnych gatunkami rodzimymi, zwłaszcza długowiecznymi, takimi jak dęby, lipy i klony.

Konieczna jest także polityka władz gminnych ukierunkowana na opracowanie katalogu standardów inwestycji, w odniesieniu do promowania lokalnych zasobów krajobrazu w przestrzeni prywatnej i ze szczególnym uwzględnieniem lokalnej tradycji:

- przydomowych ziołowo-kwiatowych ogrodów poprzez wprowadzanie rodzimych gatunków drzew i krzewów użytkowych,

- sadowniczo-pszczelarskiej oraz zwyczajowego sadzenia drzew liściastych - „strażników domu", a także alei i zadrzewień śródpolnych,

- budowlanej, uwzględniającej układ zagrodowy, kubaturę budynków i detal architektoniczny oraz formę i materiał (tj. drewno, cegła) ogrodzeń i bram (usunięcie starych słupów betonowych oraz prefabrykatów).

\section{Wariant rozwoju turystyki kulturowej}

Po akceptacji społecznej proponowanych zmian oraz skutecznym ich wprowadzeniu można podjąć działania zmierzające do realizacji kolejnych etapów odnowy wsi, które uwzględnią całościową wizję jej rozwoju, zgodną z lokalnym dziedzictwem kulturowym i krajobrazem rolniczym oraz uwarunkowaniami regionalnymi. Turystyka kulturowa jest szansą dla regionów takich jak Wielkopolska, gdzie dominujący krajobraz rolniczy nie ma szansy konkurować z atrakcyjnymi przyrodniczo obszarami nadmorskimi czy górami. Rekompensatą jest tu bogactwo zasobów kulturowych, które we właściwy sposób odczytane i wykorzystane mogą stać się motorem rozwoju i promocji regionu (Raszeja i Wolska 2009). Związek gminy Murowana Goślina, a tym samym wsi Długa Goślina, z jej otoczeniem jest silny, gdyż została ona włączona w szereg projektów międzygminnych również poprzez ochronę obszarów cennych przyrodniczo i kulturowo. Jest to nobilitujące dla mieszkańców i powinno zachęcać ich do dalszych działań w kierunku uczytelnienia kontekstu kulturowości w szerszym wymiarze, a więc nie tylko poprzez dostrzeganą architekturę sakralną, ale także poprzez historyczną architekturę folwarczną i zagrodową, tzw. architekturę niedostrzeganą (Łęcki i in. 1994) oraz organizację funkcjonalno-przestrzenną wsi, jak i jej rozłogu. Zadaniem proponowanego wariantu rozwoju turystki kulturowej jest podkreślenie, uczytelnienie tych relacji przestrzennych. W przypadku omawianej wsi działania odnowy powinny zmierzać do wytyczenia i oznakowania szlaku obejmującego wszystkie zasoby wsi, które składają się na charakterystyczny typ krajobrazu kulturowego:

- krajobraz kulturowy rolniczy z uwzględnieniem różnorodnych form zieleni wysokiej, tj. zadrzewień śródpolnych, przydrożnych, towarzyszących ciekom - proponowany szlak korzystałby częściowo z już istniejących tras szlaku zielonego i pomarańczowe- 
go, włączając grodzisko stożkowe (konieczne byłoby utworzenie kładki na terenach okresowo zalewowych i podmokłych);

- krajobraz kulturowy osadniczy wraz z historyczną zabudową dworską i folwarczną (wskazana rekonstrukcja parku dworskiego oraz modernizacja i adaptacja dawnej gorzelni), zabudową zagrodową i towarzyszącą jej zielenią (sady, drzewa „strażnicy zagród", kwiatowo-ziołowe ogrody podokienne) oraz zabytkowym obiektem sakralnym (wskazane byłoby zasygnalizowanie w przestrzeni wsi istniejących niegdyś obiektów - młyna wodnego i karczmy). Konieczne wydaje się również zorganizowanie punktów widokowo-wypoczynkowych, skierowanych na siedlisko i uwypuklających jej czytelną sylwetę, dających możliwość dalekiego widoku.

Proponowane działania mogą przyczynić się także do rozwoju, m.in. agroturystyki, turystyki rowerowej, kulinarnej, a także towarzyszących im usług, takich jak: jeździectwo, wędkarstwo, rękodzieło. W przyszłości możliwy jest także rozwój budownictwa letniskowego lub tzw. „drugich domów”. W tym kontekście szczególnie istotne jest wskazanie potencjalnej lokalizacji tego typu obiektów oraz ich harmonijne wkomponowanie w zidentyfikowany krajobraz kulturowy. Konieczne wydaje się również stworzenie produktu turystycznego poprzez kreatywne podejście do walorów krajobrazu oraz zasobów ludzkich. Istnieje potrzeba poszukiwania nietypowych i rzadko występujących form działalności, np. apiturystyka, enoturystyka. Szczególnym przykładem twórczego podejścia do przestrzeni może być również LandArt lub działania związane z tzw. „gospodarką doznaniami”, a w konsekwencji tematyzacja wsi.

\section{Wariant rozwoju rolnictwa ekologicznego}

Z racji dobrze funkcjonujących gospodarstw rolnych, licznych sadów i położenia w bliskim sąsiedztwie dużego miasta - bezpośredniego rynku zbytu, we wsi Długa Goślina możliwy byłby kierunek rozwoju w oparciu o koncepcję rolnictwa ekologicznego. Kierunek ten może być traktowany jako alternatywny lub komplementarny do wcześniej wskazanego wariantu rozwoju turystyki kulturowej. Jego celem powinno być zachowanie i podtrzymanie funkcji krajobrazu rolniczego wsi (upraw rolniczych, upraw sadowniczych, a także wprowadzaniu upraw ekologicznych), przy równoczesnej dbałości o system zadrzewień śródpolnych, szczególnie ważnych dla dobrej kondycji upraw (Karg i Karlik 1993). Zadrzewienia śródpolne pełnią przede wszystkim rolę klimatyczną, wiatrochronną i wodochronną, biocenotyczną, sanitarno-higieniczną, a także rozgraniczają własność, zasłaniają i maskują niekorzystne elementy krajobrazu. Ponadto ochrona środowiska w ramach działalności rolniczej jest także korzystna ze względu na możliwość pozyskania środków finansowych z programów rolnośrodowiskowych (Kaługa 2009; Kacprzak i Kołodziejczak 2011). Jednocześnie racjonalne sposoby gospodarowania - stosowanie w rolnictwie technik przyjaznych środowisku - zmniejszają koszty funkcjonowania gospodarstw rolnych, wpływając na zwiększenie ich rentowności. Zachowanie bogatej różnorodności biologicznej na terenie gospodarstwa i w jego otoczeniu zwiększa jego opłacalność poprzez możliwość prowadzenia działalności uzupełniającej o wysokiej wartości dodanej, na którą istnieje duży popyt, np. agroturystyka, sprzedaż produktów i przetworów ekologicznych oraz wyrobów rzemieślniczych. Wiele rozpoznawalnych, certyfikowanych produktów ekologicznych jest wytwarzanych na obszarach cennych przyrodniczo i kulturowo, stanowiąc uzupełnienie produktu turystycznego. Działania na rzecz tworzenia marki produktu re- 
gionalnego mogą zatem tematyzować przestrzeń i godzić interesy ochrony przyrody oraz kształtowania krajobrazu kulturowego z rozwojem terenów wiejskich.

W realizacji działań proponowanych w ramach poszczególnych etapów i wariantów rozwoju wsi warto zwrócić uwagę na różnorodne formy zieleni i tworzące je rodzime gatunki drzew oraz roślin użytkowych, gdyż mogą one pełnić szereg istotnych funkcji (tab. 2).

Tabela 2. Zalecane formy zieleni i gatunki roślin użytkowych w organizacji struktury funkcjonalno-przestrzennej wsi

\begin{tabular}{|c|c|c|}
\hline Forma zieleni & Przykładowe gatunki & Podstawowa funkcja/zastosowanie \\
\hline $\begin{array}{l}\text { Zadrzewienia i aleje } \\
\text { przydrożne }\end{array}$ & lipa, kasztanowiec, robinia, jesion & gatunki miododajne \\
\hline Zadrzewienia śródpolne & $\begin{array}{l}\text { lipa, grab, dąb, jesion, wiąz, kasztano- } \\
\text { wiec, wierzba }\end{array}$ & $\begin{array}{l}\text { materiał stolarski, snycerski } \\
\text { i wikliniarski }\end{array}$ \\
\hline Zakrzewienia śródpolne & $\begin{array}{l}\text { dzika róża, bez czarny, śliwa ałycza, } \\
\text { jarząb, rokitnik, tarnina, głóg }\end{array}$ & $\begin{array}{l}\text { gatunki miododajne oraz jadalne } \\
\text { znajdujące zastosowanie głównie } \\
\text { w przetwórstwie i farmacji }\end{array}$ \\
\hline Zadrzewienia przydomowe & lipa, klon jawor, lilak & $\begin{array}{l}\text { funkcja ocieniająca, izolacyjna, } \\
\text { ozdobna }\end{array}$ \\
\hline Sady & jabłoń, śliwa, grusza, wiśnia, ałycza & $\begin{array}{l}\text { gatunki jadalne, zastosowanie w prze- } \\
\text { myśle rolno-spożywczym }\end{array}$ \\
\hline Ogrody przydomowe & $\begin{array}{l}\text { zioła: szałwia, macierzanka, majera- } \\
\text { nek, tymianek, malwa, dziurawiec, } \\
\text { mięta, koper, tymianek, czosnek, } \\
\text { arcydzięgiel } \\
\text { rośliny obficie kwitnące: słonecznik, } \\
\text { malwa, onętek, dalia, ostróżka, lilia, } \\
\text { mieczyk, rudbekia } \\
\text { rośliny owocujące: porzeczka, agrest, } \\
\text { malina }\end{array}$ & $\begin{array}{l}\text { pozyskiwanie kwiatów, ziół i owoców - } \\
\text { gatunki jadalne lecznicze, oraz pełnią- } \\
\text { ce funkcje terapeutyczne, edukacyjne }\end{array}$ \\
\hline Uprawy pokazowe & $\begin{array}{l}\text { jarmuż, pasternak, gryka, kalarepa, } \\
\text { rabarbar }\end{array}$ & $\begin{array}{l}\text { gatunki jadalne oraz pełniące funkcję } \\
\text { ekspozycyjno-edukacyjną }\end{array}$ \\
\hline Uprawy użytkowe & $\begin{array}{l}\text { gryka, facelia, łubin, szałwia, rzepak, } \\
\text { chmiel, chrzan, dynia, szczaw, } \\
\text { skorzonera }\end{array}$ & $\begin{array}{l}\text { gatunki jadalne i miododajne oraz } \\
\text { znajdujące zastosowanie jako zielony } \\
\text { nawóz }\end{array}$ \\
\hline Cmentarze & lipa, bluszcz, konwalia majowa & $\begin{array}{l}\text { funkcja izolująca, kompozycyjna, } \\
\text { ozdobna }\end{array}$ \\
\hline
\end{tabular}

Źródło: opracowanie własne na podstawie: J. Mowszowicz (1975), M. Chojnacka i A. Wilkaniec (2011).

Roślinność, przy niewielkim nakładzie finansowym (np. nasiona, sadzonki), daje możliwość upiększenia wsi, maskowania niekorzystnych widoków lub obiektów, wpływa na organizację struktury funkcjonalno-przestrzennej, poprawę mikroklimatu oraz jakości rolniczej przestrzeni produkcyjnej. Ponadto użytkowy charakter roślin ma istotne znaczenie w utrwalaniu dawnych zwyczajów i zawodów, podnosi walory poznawczo-wypoczynkowe wsi i może przyczynić się do stworzenia produktu turystycznego. Uzyskanie pożądanego efektu wymaga jednak wiedzy i czasu, a działania związane z urządzaniem zieleni i późniejszymi zabiegami pielęgnacyjnymi mogą przyczyniać się do wzrostu aktywności społecznej oraz wytworzenia nowych relacji wśród mieszkańców.

W procesie aktywizacji gospodarczej obszarów atrakcyjnych krajobrazowo szczególnie ważne wydaje się być zjawisko reklamy zewnętrznej. Stwierdzono niepokojącą tendencję do kumulacji reklam w otoczeniu miejsc o istotnych walorach krajobrazowych (Szczepań- 
ska i Wilkaniec 2016). Taka lokalizacja przyczynia się do ograniczenia widoczności i bezpieczeństwa jazdy, a jednocześnie degradacji walorów krajobrazowych, co jest szczególnie niekorzystne w obszarze o funkcjach turystycznych i rekreacyjnych. Działania władz samorządowych w zakresie kształtowania ładu informacyjnego i krajobrazowego mogłyby być bardziej skuteczne poprzez propagowanie dobrych wzorców nośników reklamowych i konsultacje z lokalną społecznością oraz przedsiębiorcami.

Wszystkie proponowane przedsięwzięcia w ramach odnowy wsi powinny być uzgadniane i przeprowadzone na dwóch poziomach:

- Urzędu Miasta i Gminy Murowana Goślina, poprzez wprowadzenie odpowiednich uregulowań i strategii rozwoju, opracowanie programów odnowy, katalogu standardów inwestycji oraz miejscowego planu zagospodarowania przestrzennego, uwzględniających zasoby i walory krajobrazu kulturowego, a więc po przeprowadzeniu analiz krajobrazowych,

- samorządu wsi Długa Goślina i jej mieszkańców - w przypadku niektórych proponowanych zmian, tylko aktywizacja i akceptacja społeczności lokalnej może doprowadzić do ich szybkiego i trwałego wprowadzenia.

\section{Podsumowanie}

Przestrzeń terenów wiejskich jest przestrzenią szczególnie wrażliwą na kształtowanie, ze względu na swój dobrze określony rodowód i silnie zdefiniowane własne, oryginalne cechy i właściwości, ukształtowane w harmonijnym ciągu zdarzeń na przestrzeni wielu wieków (Lipińska 2003). Jednym z warunków koniecznych dla właściwego gospodarowania obszarami wiejskimi oraz efektywnego rozwoju, a tym samym podniesienia konkurencyjności danego obszaru, jest uwzględnienie lokalnych zasobów kulturowych. To właśnie kultura warunkuje w znacznym stopniu dynamikę i kierunek rozwoju gospodarczego. Natomiast pomijanie różnych aspektów kultury w rozwoju społeczno-ekonomicznym może prowadzić do alienacji jednostek i zbiorowości czy niebezpiecznych zjawisk dezintegracji społecznej i zaburzenia ładu społecznego, a tym samym osłabić, tempo i skalę rozwoju danego obszaru (Krzyminiewska 2010a, 2010b). Możliwość połączenia i realizacji głównych celów rozwoju, np. turystyki, ze świadomym kształtowaniem i ochroną krajobrazu jest sposobem na ocalenie tego, co ważne (w perspektywie ochrony dla przyszłych pokoleń), przy jednoczesnym wykorzystaniu względów ekonomicznych (Jaszczak i Hernik 2012).

Wieś Długa Goślina wykazuje cechy typowe dla wielkopolskiej wsi-ograniczanie funkcji rolniczych na rzecz funkcji mieszkaniowych i usługowych, co powoduje deformację historycznego układu jednostki osadniczej. Natomiast pod względem zasobów krajobrazu kulturowego wieś charakteryzuje się znaczną różnorodnością walorów, które odpowiednio zinterpretowane i zagospodarowane mogą stanowić istotne podstawy rozwoju lokalnego i promocji regionu. Wydaje się, że zaproponowane warianty rozwoju dla wsi Długa Goślina mają uniwersalny charakter i przy odpowiedniej ich adaptacji do lokalnych uwarunkowań panujących w innych jednostkach osadniczych mogą znaleźć zastosowanie w przedsięwzięciach odnowy wsi na terenie Wielkopolski (ryc. 6). 


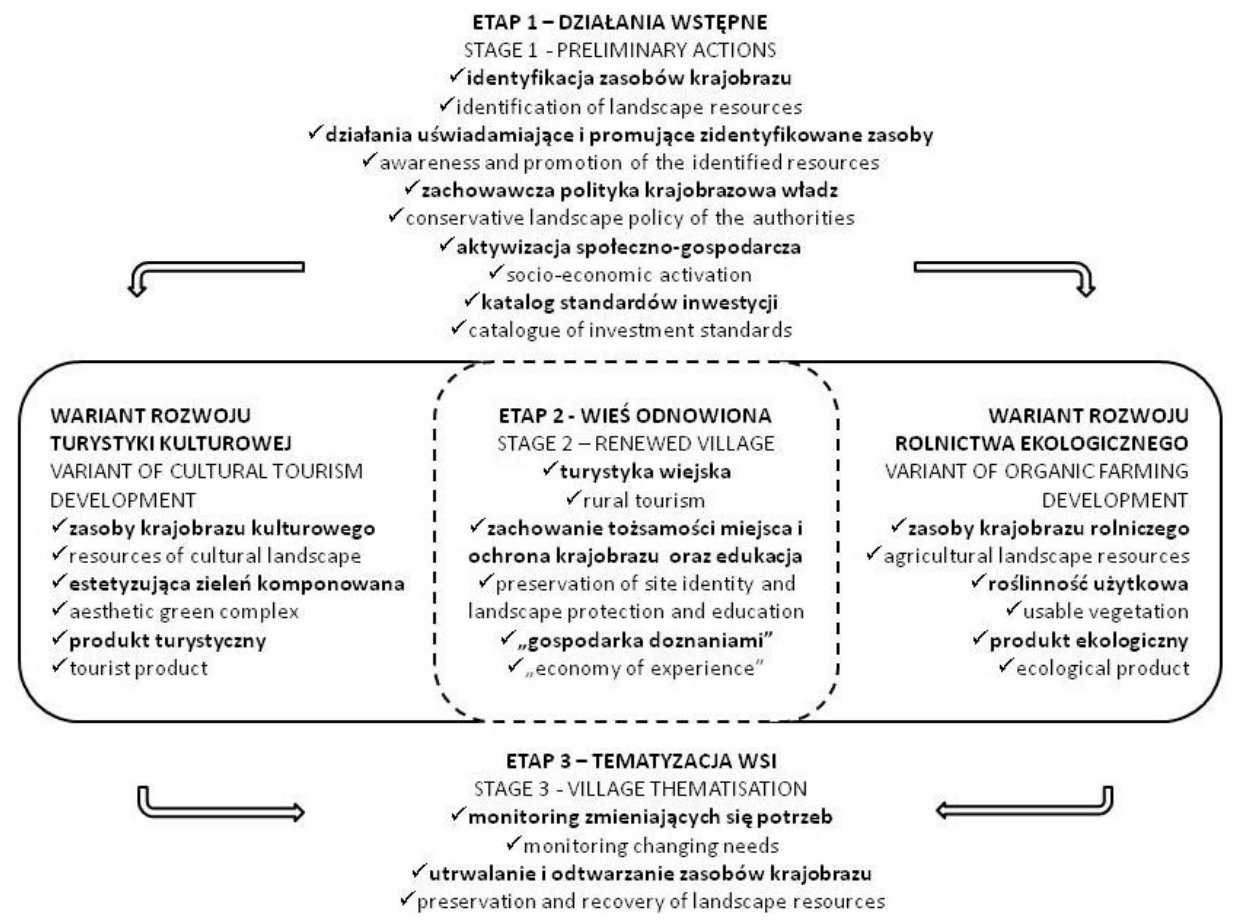

Ryc. 6. Etapy działań i warianty rozwoju wsi w ramach jej odnowy

Źródło: opracowanie własne.

Stages of actions and variants of rural development within its renewal

Source: own elaboration.

Współczesna wieś zmienia swój charakter. Jest to proces nieunikniony, ale ważne jest, aby wprowadzane zmiany czerpały z tradycji wiejskiego krajobrazu, podkreślały jego niepowtarzalne piękno i odrębność regionalną, twórczo dostosowywały do aktualnych potrzeb: mieszkaniowych, żywnościowych oraz turystyczno-wypoczynkowych, a także coraz częściej terapeutycznych, leczniczych i edukacyjnych.

\section{Literatura}

Bański J., 2008, Strefa podmiejska - już nie miasto, jeszcze nie wieś, [w:] A. Jezierska-Thöle, L. Kozłowski (red.), Gospodarka przestrzenna w strefie kontinuum miejsko-wiejskiego w Polsce, Wydawnictwo Naukowe UMK, Toruń.

Bański J., 2014, Wspótczesne typologie obszarów wiejskich w Polsce - przeglaqd podejść metodologicznych, Przegląd Geograficzny, 86, 4, s. 441-470.

Bański J., Stola W., 2002, Przemiany struktury przestrzennej i funkcjonalnej obszarów wiejskich w Polsce, Studia Obszarów Wiejskich, 3, Warszawa.

Bogdanowski J., 1976, Kompozycja i planowanie przestrzenne w architekturze krajobrazu, Ossolineum, Kraków.

Bogdanowski J., 1994, Metoda jednostek i wnętrz architektoniczno-krajobrazowych w studiach i projektowaniu, Politechnika Krakowska, Kraków. 
Bogdanowski J., 1996, Projekt standardowego opracowania problematyki ochrony wartości kulturowego krajobrazu i środowiska w studium do planu i miejscowym planie zagospodarowania przestrzennego, Krajobrazy 12 (24), Ośrodek Ochrony Zabytkowego krajobrazu, Warszawa.

Brust M., 2004, Najdawniejsze dzieje Ziemi Obornicko-Rogozińskiej w okresie od XII do końca XIV wieku na podstawie źródeł pisanych, Oborniki (maszynopis).

Chmielewski T. J., Myga-Piątek U., Solon J., 2015, Typologia aktualnych krajobrazów Polski, Przegląd Geograficzny, 87, 3, s. 377-408.

Chojnacka M., Wilkaniec A., 2011, Tradycyjny ogród wiejski - historia i współczesne inspiracje, [w:] M. E. Drozdek (red.), Zieleń miast i wsi współczesna i zabytkowa. Rośliny do zadań specjalnych, Oficyna Wydawnicza Państwowej Szkoły Zawodowej w Sulechowie, Sulechów-Kalsk, s. 193-206.

Cymerman R., Falkowski J., Hopfer A., 1992, Krajobrazy wiejskie (klasyfikacja i kształtowanie), Wydawnictwo Art., Olsztyn.

Czapiewska G., 2012, Wioski tematyczne sposobem na aktywizację gospodarczq i społecznq regionu, Studia i Materiały, Miscellanea Oeconomicae 16, 1, s. 109-123.

Duriasz-Bułhak J., Połomski K., Potok A., (red.) 2011, Rzecz o dziedzictwie na wsi. Rady, przykłady, informacje, Fundacja Wspomagania Wsi, Warszawa.

Głębocki B., 2008, Zmiany w strukturze własnościowej i użytkowaniu gruntów Poznaiu i jego sferze podmiejskiej, [w:] T. Kaczmarek, A. Mizgajski (red.), Powiat poznański. Jakość przestrzeni i jakość życia, Wydawnictwo Naukowe Bogucki, s. 177-192.

GUS, 2016, Bank Danych Lokalnych.

Heffner K., 2001, Transformacja układów osadniczych wsi a wielofunkcyjny rozwój obszarów wiejskich, [w:] A. Rosner, I. Bukraba-Rylska (red.), Wieś i rolnictwo na przełomie wieków, PAN IRWiR, Centrum Naukowo-Wdrożeniowe SGGW, Warszawa.

Hełpa-Liszkowska K., 2013, Dziedzictwo kulturowe jako czynnik rozwoju lokalnego, Studia Oeconomica Posnaniensia, 1, 6 (255), s. 7-18.

Idziak W., 2008, Wymyślić wieś od nowa. Wioski tematyczne, Alta Press, Koszalin.

Jaszczak A., Hernik J., 2012, Potencjał krajobrazów kulturowych podstawq kreacji przestrzeni rekreacyjnej. Infrastruktura i ekologia terenów wiejskich, Komisja Technicznej Infrastruktury Wsi, 3, II, PAN, Oddział w Krakowie, s. 91-104.

Kacprzak E., Kołodziejczak A., 2011, Rozwój rolnictwa ekologicznego w Polsce w latach 2006-2009, Biuletyn Instytutu Geografii Społeczno-Ekonomicznej i Gospodarki Przestrzennej, seria Rozwój Regionalny i Polityka Regionalna, 14, Uniwersytet im. Adama Mickiewicza w Poznaniu, Poznań, s. 117-136.

Kaleniewicz A., 2008, Cysterski Szlak Rowerowy w północnej Wielkopolsce, Związek Międzygminny Puszcza Zielonka, Murowana Goślina.

Kaługa I., 2009, Korzyści dla rolnictwa wynikajqqce z gospodarowania na obszarach Natura 2000, Ministerstwo Środowiska, Warszawa.

Karg J., Karlik B., 1993, Zadrzewienia na obszarach wiejskich, Zakład Badań Środowiska Rolniczego i Leśnego PAN, Poznań.

Kłoczko-Gajewska A., 2014, Can we treat thematic villages as social innovations? Journal of Central European Green Innovation, 2 (3), s. 49-59.

Kłodziński M., 1996, Wielofunkcyjny rozwój terenów wiejskich w Polsce i w krajach Unii Europejskiej, SGGW, Warszawa.

Kondracki J., 1976, Podstawy regionalizacji fizycznogeograficznej, PWN, Warszawa.

Konopka M., 2001, Każde miejsce opowiada swoja historię czyli rzecz o dziedzictwie wiejskim, Fundacja Fundusz Współpracy, Poznań. 
Kostrowicki J., 1976, Obszary wiejskie jako przestrzeń wielofunkcyjna. Zagadnienia badawcze i planistyczne, Przegląd Geograficzny 68, 4, s. 601-611.

Kruczek Z., Walas B., 2009, Nowoczesne postrzeganie promocji kulturowych produktów turystycznych, [w:] A. Stasiak (red.), Kultura i turystyka - wspólnie zyskać, Wydawnictwo Wyższej Szkoły Turystyki i Hotelarstwa, Łódź, s. 335-360.

Krzyminiewska G., 2010a, Kultura ekonomiczna młodzieży wiejskiej i jej znaczenie w rozwoju społeczno-gospodarczym obszarów wiejskich, Wydawnictwo Uniwersytetu Ekonomicznego w Poznaniu, Poznań.

Krzyminiewska G., 2010b, Kulturowe aspekty rozwoju obszarów wiejskich, [w:] S. Sokołowska, A. Mijal (red.), Wieś i rolnictwo w procesie zmian, Czynniki rozwoju obszarów wiejskich, Uniwersytet Opolski, Opole.

Kulse N., Wojczak Z., 2004, Murowana Goślina i okolice. Przewodnik, Murowana Goślina.

Lipińska B., 2003, Kultura użytkowania przestrzeni-degradacja krajobrazu wiejskiego [w:] I. Liżewska, W. Knercer (red.), Zachowane-ocalone? O krajobrazie kulturowym i sposobach jego ksztattowania, Wydawnictwo Stowarzyszenie WK „Borussia”, Olsztyn, s. 128-137.

Łęcki W., Jakimowicz T., Nowak H., 1994, Architektura Niedostrzegana, Wydawnictwo Abos, Poznań, s. 17-27.

Małek J., 2003, Turystyka kulturowa jako czynnik rozwoju lokalnego, Prace i Studia Geograficzne, 32, Warszawa.

Messtischblatt, 1940, http://mapy.amzp.pl (dostęp on-line: 24 marca 2016)

Mowszowicz J., 1975, Dziko rosnqce rośliny użytkowe, Wydawnictwa Szkolne i Pedagogiczne, Warszawa.

Murzyn-Kupisz M., 2012, Dziedzictwo kulturowe a rozwój lokalny, Zeszyty Naukowe, Uniwersytet Ekonomiczny w Krakowie, Seria Specjalna, Monografie, 221, 350.

Myga-Piątek U., 2014, Ocena wartości i zagrożeń krajobrazów kulturowych Polski, Perspektywa Europejskiej Konwencji Krajobrazowej, Samorząd Terytorialny, 12, s. 7-19.

Niedźwiecka-Filipiak I., 2007, Idealny projekt odnowy wsi w praktyce, VI Europejski Kongres Odnowy Wsi w Kamień Śląskim, Materiały konferencyjne dostęp on-line: czerwiec 2017 http:// www.umwd.dolnyslask.pl/fileadmin/user_upload/WROW/ODNOWA_WSI_DLS/prezentacje/ irena.pdf

Niedźwiecka-Filipiak I., 2009, Wyróżniki krajobrazu i architektury wsi Polski Południowo-Zachodniej, Wydawnictwo Uniwersytetu Przyrodniczego we Wrocławiu, Wrocław.

Niedźwiecka-Filipiak I., 2015, Walory miejscowości - tworzywem Sieci Najciekawszych Wsi, Urząd Marszałkowski Województwa Opolskiego, Opole.

Ortofotomapa 2016, www.geoportal.gov.pl (dostęp on-line: 24 marca 2016).

Parysek J., 2001, Podstawy gospodarki lokalnej, Wydawnictwo Naukowe UAM, Poznań.

Parysek J., 2008, Procesy suburbanizacyjne w aglomeracji poznańskiej [w:] T. Kaczmarek, A. Mizgajski (red.), Powiat poznański. Jakość przestrzeni i jakość życia, Wydawnictwo Naukowe Bogucki, Poznań, s. 71-90.

Plit F., 2016, Krajobrazy kulturowe w geografii polskiej - szkice, Wydawnictwo Akademickie Dialog, Warszawa.

Plan Odnowy Sołectwa Długa Goślina na lata 2010-2017, Urząd Miasta i Gminy Murowana Goślina 2010, http://bip.murowana-goslina.pl/pliki/uchwaly/2007-10/401_2010.pdf (dostęp on-line: 24 marca 2016).

Raszeja E., 2013, Ochrona krajobrazu w procesie przekształceń obszarów wiejskich, Wydawnictwo Uniwersytetu Przyrodniczego w Poznaniu, Poznań. 
Raszeja E., Wilkaniec A., De Mezer E., 2010, Krajobraz i dziedzictwo kulturowe wsi w aglomeracji poznańskiej, Bogucki Wydawnictwo Naukowe, Poznań.

Raszeja E., Wolska N., 2009, Rozwój rekreacji z wykorzystaniem istniejq̨cych zasobów kulturowych w małych jednostkach osadniczych Wielkopolski, Nauka Przyroda Technologie, 3, 1, \#35.

Richling A., Solon J., 1994, Ekologia krajobrazu, PWN, Warszawa.

Solon J., Chmielewski T.J., Myga-Piątek U., Kistowski M., 2015, Identyfikacja i ocena krajobrazów Polski - etapy i metody postępowania w toku audytu krajobrazowego w województwach, Problemy Ekologii Krajobrazu, 40, s. 55-76.

Studium uwarunkowań i kierunków zagospodarowania przestrzennego gminy Murowana Goślina, 2009, Uchwała Rady Miejskiej w Murowanej Goślinie nr XXXIII/321/2009, z dnia 28 września $2009 \mathrm{r}$.

Sulimierski F., Chlebowski B., Walewski W., 1880, Słownik geograficzny Królestwa Polskiego i innych krajów słowiańskich, Warszawa.

Szafrański W., 2013, Romańszczyzna w Murowanej Goślinie pod Poznaniem. Na tropie wieży mieszkalnej we wczesnośredniowiecznej włości rycerskiej, Fontes Archaeologoci Posnanienses, XXVI, 1975, Poznań, s. 156-167.

Szczepańska M., 2014, Świadomość i aktywność społeczna w zakresie kształtowania i ochrony krajobrazu kulturowego obszarów wiejskich, Rozwój Regionalny i Polityka Regionalna, 26, Wydawnictwo Bogucki, Poznań, s. 135-148.

Szczepańska M., Wilkaniec A., 2014, Przekształcenia krajobrazu kulturowego wybranych wsi strefy podmiejskiej Poznania, Studia Obszarów Wiejskich, 35, s. 45-60.

Szczepańska M., Wilkaniec A., 2016, Outdoor advertising in the cultural landscape of rural areas attractive in tourist terms, Studia Obszarów Wiejskich, 43, s. 87-100.

Wilczyński R., 2012, Sieć najpiękniejszych wsi. Opracowanie eksperckie projektu-możliwości utworzenia sieci, Opole. (http://www.dziedzictwowsiopolskiej.pl/upload/users/krybak/files/opracowanie_koncepcji_najpiekniejszych_wsi_fina\%C5\%82.pdf (dostęp on-line: 24 marca 2016).

Wilczyński R., 2003, Odnowa wsi perspektywa rozwoju obszarów wiejskich w Polsce, Krajowe Centrum Doradztwa Rozwoju Rolnictwa i Obszarów wiejskich, Poznań.

Wilczyński R., 2007, 10 lat odnowy wsi w Polsce - droga do celu, [w:] M. Kłodziński, M. Błąd i R. Wilczyński (red.), Odnowa wsi w integrujqcej się Europie, Instytut Rozwoju Wsi i Rolnictwa Polskiej Akademii Nauk, s. 67-76.

Wójcik M., 2013, Przemiany społeczno-przestrzenne osiedli wiejskich. Studium przypadku Łódzkiego obszaru metropolitarnego, Wydawnictwo Uniwersytetu Łódzkiego, Łódź.

\section{Summary}

In rural areas, there is a wealth of historical resources of the cultural landscape which may determine the socio-economic development of these areas. Given the explosive transformation of the modern countryside, there is an urgent need to find effective tools and methods to protect its cultural heritage. This protection cannot be limited to "freezing" historical forms; it should involve proactive measures affecting the quality of the landscape and the functionality of those areas, which can significantly increase their development potential.

The relevant landscape research was conducted in the Długa Goślina village in the Wielkopolska Province. After identifying resources of the village's cultural landscape and 
determining state of their behaviour and analysing planning documents, an attempt was made to identify the opportunities and the threats to the area's development. The aim of the research was to identify activities within the framework of village renewal, as potential development scenarios, possibly also implemented in other settlement units.

Długa Goślina has features typical of a Wielkopolska village: the agricultural function limited to residential and service functions, which causes a deformation of the historical village pattern. But in terms of resources, its cultural landscape has a considerable diversity of values, which when properly interpreted and developed, can be an important basis of local development. For the village under study, preliminary conservation works were proposed. Once the public accepts these activities and effective implementation of them, it will be possible to prepare a scenario for the development of cultural tourism. Given the functioning of agricultural holdings and close market, optional or parallel development would be based on the concept of organic farming.

It seems that the proposed development directions for Długa Goślina have a universal character and, when properly adapted to the local conditions prevailing in other settlements, can be used in village renewal projects in Wielkopolska. 